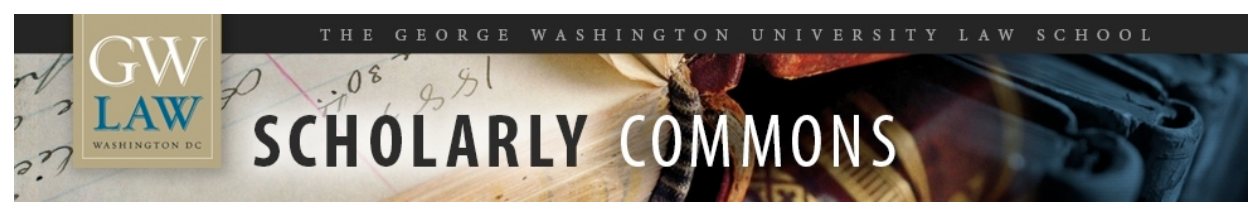

\title{
Guns, Bird Feathers, and Overcriminalization: Why Courts Should Take the Second Amendment Seriously
}

\author{
Robert J. Cottrol \\ George Washington University Law School, bcottrol@law.gwu.edu \\ George Mocsary \\ Southern Illinois University Carbondale
}

Follow this and additional works at: https://scholarship.law.gwu.edu/faculty_publications

Part of the Law Commons

\section{Recommended Citation}

Cottrol, Robert J. and Mocsary, George A., Guns, Bird Feathers, and Overcriminalization: Why Courts Should Take the Second Amendment Seriously (2016). 14 Georgetown Journal of Law \& Public Policy 17; GWU Law School Public Law Research Paper No. 2017-10; GWU Legal Studies Research Paper No. 2017-10. Available at SSRN: https://ssrn.com/abstract=2857284

This Article is brought to you for free and open access by the Faculty Scholarship at Scholarly Commons. It has been accepted for inclusion in GW Law Faculty Publications \& Other Works by an authorized administrator of Scholarly Commons. For more information, please contact spagel@law.gwu.edu. 


\title{
Guns, Bird Feathers, and Overcriminalization: Why Courts Should Take the Second Amendment Seriously
}

\author{
Robert J. Cottrol* and George A. Mocsary**

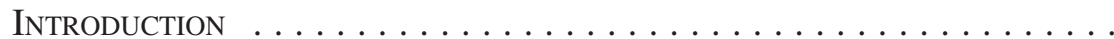

I. Levels of Second Amendment Debate . . . . . . . . . . . . . 21

A. A History Revised . . . . . . . . . . . . . . . . . 21

B. A Jurisprudence Underdeveloped . . . . . . . . . . . . . . . 24

i. From Cruikshank to Miller ................. 24

ii. From Miller to Heller . . . . . . . . . . . . . . 26

iii. Heller and Beyond . . . . . . . . . . . . . . . . 29

II. Underenforcement of the SECOnd Amendment: ReCOnSIDERING THE Consequences . . . . . . . . . . . . . . . . .

A. "Assault Weapons"-the Quintessential Demonization

Campaign .......................

B. Overcriminalization ................. 37

Conclusion .............................. 45

\section{INTRODUCTION}

It is our pleasure to participate in that hardy perennial, a debate on the Second Amendment and what should be our national policy or policies on gun control and gun ownership. Our commission, as we understand it, is to discuss how rigorously the courts should enforce the Second Amendment. At one time, less than a decade ago, we had a very different debate, a debate about the very meaning of the constitutional provision that states: "A well-regulated Militia, being necessary to the security of a free state, the right of the people to keep and

* Harold Paul Green Research Professor of Law, and Professor of History and Sociology, The George Washington University. A.B., Ph.D., Yale University, J.D., Georgetown University Law Center.

** Assistant Professor, Southern Illinois University School of Law. Fordham University School of Law, J.D., summa cum laude, 2009; University of Rochester Simon School of Business, M.B.A., 1997.

The authors would like to thank John Marshall Cottrol II, Bob Dowlut, David B. Kopel, David Karpis, Sharee S. Langenstein, Mark Overstreet, and Christopher Zealand for their valuable insights and feedback. The authors are also grateful to Jacob Kirk and Jennifer Paulson for their excellent research, and to David Stoddard for his excellent research and editing. (C) 2016, Robert J. Cottrol and George A. Mocsary. 
bear Arms, shall not be infringed."1 Powerful voices in the media, the academy, and the legislative and judicial branches of our government argued that this constitutional amendment, alone among the other provisions of the Bill of Rights, was essentially meaningless as a vehicle that might protect the rights of American citizens or others who might live under the jurisdiction and authority of the United States. ${ }^{2}$ Did the Second Amendment guarantee the right of individuals to have arms, in part for purposes of self-defense, or did it simply protect a right, largely undefined by its champions, for states to maintain militias, or perhaps for members of the organized militia to have arms? Those questions were at least temporarily answered as a matter of positive law by the Supreme Court's two twenty-first century Second Amendment decisions District of Columbia v. Heller ${ }^{3}$ and McDonald v. City of Chicago. ${ }^{4}$ The current holdings of the Supreme Court say that the amendment that states in its operative language that "the right of the people to keep and bear arms shall not be infringed," actually was meant to protect from government infringement the right of the people to keep and bear arms. Both had narrow support with five supporting justices and four dissenters. Both decisions have been called mistakes and have been subject to calls for reversal from, among others, Justice Ruth Bader Ginsburg and former Justice John Paul Stevens. ${ }^{5}$ But the decisions still stand, and, it should be added, they have a great deal of popularity with the American people, protesting jurists and academics notwithstanding. ${ }^{6}$

On March 21, 2016, the Supreme Court issued a decision which strengthened the precedents put forward in Heller and McDonald. In a per curium decision in the case of Caetano v. Massachusetts, the Court vacated the judgment of the Massachusetts Supreme Judicial Court and remanded the case for further examination consistent with Heller. ${ }^{7}$ The Massachusetts court held that stun guns were not protected by the Second Amendment because they employed a technology unknown at the time of its adoption. ${ }^{8}$ Caetano confirmed the decisions in

1. U.S. Const. amend. II.

2. See, e.g., Warren Burger, The Right to Bear Arms, PARAdE MAG., Jan. 14, 1990, at 4.

3. District of Columbia v. Heller, 554 U.S. 570, 591 (2008) (holding that the Second Amendment protects an individual right to arms for purposes of self-defense, independent of militia service).

4. McDonald v. City of Chicago, 561 U.S. 742, 749 (2010) (holding that the Second Amendment was incorporated and restricted the states as well as the federal government).

5. Interview by John Hockenberry with Ruth Bader Ginsburg (Sept. 16, 2013) (transcript archived at http://perma.cc//SW5Q-26WT); John Paul Stevens, The Five Extra Words that Can Fix the Second Amendment, WASH. Post (Apr. 11, 2014), https://www.washingtonpost.com/opinions/the-five-extra-wordsthat-can-fix-the-second-amendment/2014/04/11/f8a19578-b8fa-11e3-96ae-f2c36d2b1245_story. html?utm_term =.c8e994121b17.

6. Robert J. Cottrol, Second Amendment: Not Constitutional Dysfunction, but Necessary Safeguard, 94 B.U. L. REv. 835, 840-41 (2014).

7. Caetano v. Massachusetts, 136 S. Ct. 1027, 1028 (2016) (per curiam).

8. Id. at 1028. On July 6, 2016, Ms. Caetano was formally exonerated: the charges against her were dropped, she was formally found not guilty, and the record was sealed. Eugene Volokh, Charges Dropped in Caetano v. Massachusetts Second Amendment Stun Gun Case, Volokh Conspiracy (July 7 , 2016), https://www.washingtonpost.com/news/volokh-conspiracy/wp/2016/07/07/charges-dropped-incaetano-v-massachusetts-second-amendment-stun-gun-case. 
Heller and McDonald that the Second Amendment protected a right of individuals against infringement by state authorities. Caetano also broke new ground by indicating that the Second and Fourteenth Amendments protected arms that employed new technologies and, implicitly given that Ms. Caetano used her stun gun outside her home, that the right to bear arms extended outside the home. ${ }^{9}$ The details of the case are perhaps less important than the fact that a unanimous Court including Justices Ginsburg and Stephen Breyer, who had dissented in Heller, and Justice Sonia Sotomayer, who had joined the dissent in McDonald, joined the per curium decision.

But how rigorously should these decisions be enforced? What levels of scrutiny should the courts adopt to deal with the new regime recognizing constitutional limitations on the regulation of arms? Which arms are protected? In which venues? These and related questions can be answered in part by surveying the terrains over which Second Amendment battles, and firearms policy more generally, have been waged. One is a constitutional-historical landscape, in which the debate has gone back and forth over the original meaning and subsequent judicial interpretations of the Second Amendment. ${ }^{10}$ More perceptive students of the subject have also realized that the original meaning and subsequent interpretations of the Fourteenth Amendmentparticularly the relation between that amendment and the application of the Bill of Rights to the states-is of particular interest to those concerned with the Constitution and what it says about the citizen's right to arms. ${ }^{11}$ Another battlefield has been the courts, especially in recent years since Heller and McDonald became law. Here, the constitutional-historical debate is the foundation onto which policy arguments and empirical claims are layered.

We will review both the historical-constitutional and jurisprudential debates. But we also want to do something more. There has been one potential battle that has been left un-joined, one bit of contestable territory that has not been well explored in the ongoing debate on the Constitution and firearms policy. This under-explored landscape links lessons the constitutional and empirical debates and combines them with some of the most fundamental questions raised in criminal law: Who should we punish? Why? What is the role of proportionality

9. Id.; see id. (Alito, J., concurring) (describing Ms. Caetano's encounter with her violent exboyfriend). Caetano addresses the former point by noting that Heller held that "the Second Amendment "extends . . . to . . . arms . . . that were not in existence at the time of the founding." Id. at 1028. Before Caetano, however, one might have read Heller as referring only to gunpowder arms.

10. There is an extensive literature on the history of the Second Amendment. We will not attempt to enumerate it here. Three book-length treatments have been especially influential: SAUL Cornell, A Well-Regulated Militia: The Founding Fathers and the Origins of Gun Control in America (2006); Stephen P. Halbrook, The Founder's Second Amendment: Origins of the Right to Bear Arms (2008); and Joyce Lee Malcolm, To Keep and Bear Arms: The Origins of Anglo-American Right (1994).

11. See, e.g., Akhil Reed Amar, the Bill of Rights: Creation and Reconstruction 48-52, 83-88 (1998); Michael Kent Curtis, No State Shall Abridge: The Fourteenth Amendment and the Bill of Rights 24, 43, 52-56, 74, 138-41, 164, 170, 203 (1986). See also Robert J. Cottrol \& Raymond T. Diamond, The Second Amendment: Toward an Afro-Americanist Reconsideration, 80 Geo. L.J. 309, 342-49 (1991). 
in punishment? ${ }^{12}$ Should the state's approach to malum prohibitum (wrong because the state has deemed them so, often for transient policy reasons) ${ }^{13}$ crimes be different from its approach to malum in se (inherently evil) ${ }^{14}$ crimes? What should we do when a utilitarian objective of the criminal justice system, deterrence for example, can only be achieved through the infliction of punishments that are grossly disproportionate and, indeed, at the end of the day, unjust? ${ }^{15}$ These elementary questions usually occupy and vex first-year law students during their first weeks studying criminal law. These issues are often forgotten or only dimly remembered as part of an early first-year hazing ritual before the criminal law class gets down to the serious business of defining the elements of crimes and learning a bit about the Model Penal Code and contemporary penal statutes. As the student progresses to take criminal procedure in subsequent years, and perhaps take advanced courses in criminal law and procedure, and later still goes on to a career as a prosecutor or defense attorney, the memory of these early "philosophical" or "policy" discussions in the first weeks of the first year of law school become even more dim, clouded by the practical business of day-to-day prosecution or defense of criminal defendants.

Yet these fundamental questions also have a bearing on how vigorously the courts should enforce the Second Amendment. If the historical debate provides a key to the legitimacy of the individual rights interpretation of the Second Amendment at the heart of Heller and McDonald, and the criminological debate provides an important guide to the likely consequences of rigorous or lax enforcement of the constitutional provision, an examination of the most fundamental criminal law questions might be the key to understanding whether firearms regulations can have unintended or counterproductive consequences. To what extent does stricter firearms legislation increase public safety, or to what extent does it create a new class of victimless crimes? Does such legislation end up shifting the burden of crime reduction from career criminals to peaceable citizens? These too are issues that must be considered within the context of the Second Amendment's enforcement. Among other issues, we argue that the question of Second Amendment enforcement has to be linked to our longstanding concerns with overcriminalization and its consequences. ${ }^{16}$

12. See, e.g., Stephen Smith's discussion of proportionality and moral blameworthiness as essential elements in constructing a system of criminal justice in, Stephen F. Smith, Proportionality and Federalization, 91 VA. L. Rev. 879, 880-88 (2005). See also Alice Ristroph, Proportionality as a Principle of Limited Government, 55 DuKE L.J. 263 (2005) (discussing proportionality as a limitation on the power to punish).

13. A malum prohibitum offense is one that "is a crime merely because it is prohibited by statute, although the act itself is not necessarily immoral.” BLACK's LAW DictionARY 1103 (10th ed. 2014).

14. A malum in se offense "is inherently immoral, such as murder, arson, or rape." BLACK's LAW DictionARY 1103 (10th ed. 2014); see infra text accompanying notes 128-133.

15. Ristroph, supra note 12, at 279-84.

16. See, e.g., Sanford H. Kadish, The Crisis of Overcriminalization, 374 Annals Am. Acad. Pol. \& Soc. ScI. 157 (1967); Ekow N. Yankah, A Paradox in Overcriminalization, 14 New CRIM. L. Rev. 1 


\section{Levels of Second Amendment Debate}

The historical-constitutional and jurisprudential developments of Second Amendment discourse suggest attempts to establish decidedly revisionist accounts of the nature of the American right to arms. This Part discusses some of these efforts to steer each strand of the debate.

\section{A. A History Revised}

There is an all too facile narrative that has developed in the wake of the Court's rulings in Heller and McDonald. It argues that there had been a universal and longstanding understanding that the Second Amendment did not protect the right of individuals to keep and bear arms, but only the right of states to maintain militias or for members of the organized militia to keep and bear arms. According to this narrative, the traditional understanding only changed, and helped produce the Court's decisions in Heller and McDonald, because of vigorous advocacy by the National Rifle Association. The NRA's efforts were joined in the 1990s, the story goes, by legal scholars eager to explore a then largely uncharted territory in the field of constitutional law. This explanation for Heller and McDonald has been taken up by distinguished members of the legal academy including Erwin Chemerinsky, Dean of University of California, Irvine School of Law School. Dean Chemerinsky informs us, without citing any cases, that "[f]rom 1787 until 2008 the Court said that the Second Amendment protects only a right to have firearms for militia service. But in District of Columbia v. Heller (2008) the Court struck down a thirty-five-year-old District of Columbia ordinance prohibiting private possession of handguns." ${ }^{\text {"17 }}$ Similarly, Harvard Law School professor Cass Sunstein authored an article entitled How the Gun Lobby Rewrote the Second Amendment also arguing that the individual rights view of the amendment was of recent vintage, owing more to the activism of the NRA than the original understandings of the amendment and subsequent Supreme Court cases. ${ }^{18}$

The idea of a private right to arms only recently discovered by an activist Court prodded by a political interest group is at sharp variance with the historical record. Our best evidence indicates that the men who wrote, debated and ultimately adopted the Constitution including the Bill of Rights and the Second Amendment saw a necessary connection between the private ownership of arms and the citizen's ability to serve in the militia. A century before the adoption of the American Constitution, the principle that the law protected the

(2011); Ellen S. Podgor, Introduction Overcriminalization: New Approaches to a Growing Problem, 102 J. CRim. L. \& CRiminology 529 (2012).

17. Erwin Chemerinsky, 10 Lessons from Chief Justice Roberts' First 10 years, ABA Journal (Sept. 30, 2015, 8:30 AM), http://www.abajournal.com/news/article/chemerinsky_10_lessons_from_chief_ justice_roberts_first_10_years/.

18. Cass Sunstein, How the Gun Lobby Rewrote the Second Amendment, Bloomberg VIEw (Oct. 7 , 2015, 2:56 PM), http://www.bloombergview.com/articles/2015-10-07/how-the-gun-lobby-rewrote-thesecond-amendment. 
citizen's right to own arms was stated as a political principle in the English Bill of Rights of 1689. That English Bill of Rights, which was a statute, not a part of a constitution, contained a provision protecting the right of Protestants to own arms. ${ }^{19}$ In the rough English colonies of seventeenth- and eighteenth-century America, regular police and military forces were rare. The defense of colonies from external enemies and internal law-breakers was accomplished by armed citizens formed into militias and posses. The Framers were well aware of this history and the fact that militias had played a significant part in the rebellion against English rule. The armed population, or at least the armed population of adult white men, constituted an inchoate militia, one that was familiar with the arms of the day from their private pursuits, hunting, and self-defense. This force could be called upon for the defense of the community. It was also seen as a potential hedge against a government that might overstep its authority and turn tyrannical. This notion of the population at large as an inchoate militia that could aid in the common defense and also resist potential tyranny was well known to the framing generation and was indorsed by James Madison, Alexander Hamilton, and other champions of the new constitution. ${ }^{20}$

The earliest legal commentaries also saw the Second Amendment as protecting the right of individuals to their private weapons. One of the most important early commentators on American law and the American Constitution was Virginia jurist St. George Tucker. Tucker edited the first American edition of Blackstone's Commentaries, a series of discussions on the common law of England. Blackstone in his Commentaries discussed the right to have arms at English law. Tucker compared the English right to arms, as outlined by Blackstone, with its American counterpart. Tucker pointed out that the American right was more robust and that it, unlike the right in England, was not hampered by game laws that Tucker argued had effectively disarmed much of the English population. Published in 1803, Tucker's Blackstone provides one of the most authoritative examples of how the Constitution, including the Second Amendment, was viewed as a legal document in the infancy of the nation's constitutional history. $^{21}$

If the generation that proposed, debated, and ratified the Constitution and its first ten amendments gave every indication that it saw "the right to keep and bear arms" as a right of individuals related to, but not limited by, militia service, the Reconstruction-era Republicans who placed the Fourteenth Amendment into the Constitution indicated that they intended that their addition would make the right to keep and bear arms, along with the other provisions of the Bill of

19. Bill of Rights, 1 W. \& M., sess.2, c.2 (1689) (Eng.).

20. The Federalist No. 29, at 183 (Alexander Hamilton) (The Heritage Press 1945); The Federalist No. 26, at 319 (James Madison) (The Heritage Press 1945).

21. Blackstone's Commentaries with Notes of Reference to the Constitution and Laws, of the Federal Government of the United States; and of the Commonwealth of Virginia in Five Volumes, Vol. 1, 143 n.41 (St. George Tucker, ed., Philadelphia, William Young Birch and Abraham Small, 1803). 
Rights, binding on the states. The prevailing constitutional doctrine before the Civil War had been that the Bill of Rights only protected citizens from infringements by the Federal Government, not violations of basic rights by the states. But the struggle against slavery, the limitations on the rights of abolitionists to speak out against "the Peculiar Institution" before the War of the Rebellion had caused many Republicans to believe that the rights guaranteed by the Bill of Rights had to be protected against actions by both the states and the federal government. If the violations of the right to speak or publish weren't enough to convince most Republicans that basic rights needed to be protected against infringement by state governments, the Black Codes passed in the wake of the Civil War helped persuade others that federal protection-constitutional protection-was needed. The Black Codes were legislative enactments passed in the Southern states in 1865 and 1866 . They prescribed a number of legal disabilities for the newly freed black population. ${ }^{22}$ For many northern Republicans, the most odious of these were prohibitions on blacks owning arms. The prospect that the white South, composed of former Confederate soldiers and their sympathizers would remain armed while the black South, many of whom were Union Veterans would be disarmed by law enraged many Republican members of Congress. One of them, Representative Sidney Clarke of Kansas, during debates on the Civil Rights Act of 1866 expressed the views of many Republicans on the need to protect the right of the freedmen to have arms, a right he saw as quite distinct from service in the militia:

Who, sir were those men? Not the present militia, but the brave black soldiers of the Union, disarmed and robbed by the wicked and despotic order. Nearly

22. For example, Mississippi passed the following:

Sec. 1. Be it enacted,. . . That no freedman, free negro or mulatto, not in the military service of the United States government, and not licensed so to do by the board of police of his or her county, shall keep or carry fire-arms of any kind, or any ammunition, dirk or bowie knife, and on conviction thereof in the county court shall be punished by fine, not exceeding ten dollars, and pay the costs of such proceedings, and all such arms or ammunition shall be forfeited to the informer; and it shall be the duty of every civil and military officer to arrest any freedman, free negro, or mulatto found with any such arms or ammunition, and cause him or her to be committed to trial in default of bail.. . .

Sec. 3. If any white person shall sell, lend, or give to any freedman, free negro, or mulatto any fire-arms, dirk or bowie knife, or ammunition, or any spirituous or intoxicating liquors, such person or persons so offending, upon conviction thereof in the county court of his or her county, shall be fined not exceeding fifty dollars, and may be imprisoned, at the discretion of the court, not exceeding thirty days... .

Sec. 5. If any freedman, free negro, or mulatto, convicted of any of the misdemeanors provided against in this act, shall fail or refuse for the space of five days, after conviction, to pay the fine and costs imposed, such person shall be hired out by the sheriff or other officer, at public outcry, to any white person who will pay said fine and all costs, and take said convict for the shortest time.

1865 Miss. Laws 166 (Nov. 29, 1865). For more, see Nicholas J. Johnson, David B. Kopel, George Mocsary \& Michael P. O’Shea, Firearms Law and the Second Amendment: Regulation, Rights, and POLICY 290-92 (2012). 
every white man in [Mississippi] that could bear arms was in the rebel ranks. Nearly all of their able bodied colored men who could reach our lines enlisted under the old flag. Many of these brave defenders of the nation paid for their arms with which they went to battle. And I regret, sir, that justice compels me to say, to the disgrace of the Federal Government, that the "reconstructed" state authorities of Mississippi were allowed to rob and disarm our veteran soldiers and arm the rebels fresh from the field of treasonable strife. Sir, the disarmed loyalists of Alabama, Mississippi and Louisiana are powerless today, and oppressed by the pardoned and encouraged rebels of those states. ${ }^{23}$

The concerns expressed by Clarke and other Republican members would find their way into the debates over the Fourteenth Amendment, which among other purposes, was designed to ensure the Constitutionality of the Civil Rights Act of 1866. The debates over the Fourteenth Amendment in the Thirty-Ninth Congress give strong evidence that the supporters of the new constitutional provision intended the Privileges or Immunities Clause to protect citizens from state infringements of rights guaranteed by the Bill of Rights. ${ }^{24}$

\section{B. A Jurisprudence Underdeveloped}

Second Amendment jurisprudence has taken place in three eras. The first began shortly after the Civil War, when southern whites felt threatened by the new class of Freedmen, and it continued through an era of labor and immigrant unrest. The second began with the passage of the National Firearms Act of 1934, which heralded an era of ever-increasing trust in government protection. The third began when the Supreme Court confirmed in District of Columbia $v$. Heller that the Second Amendment protected an individual right to keep and bear arms for self-defense. ${ }^{25}$

\section{i. From Cruikshank to Miller}

As the history of the Second and Fourteenth Amendments provides little support for the notion that the Constitution was not meant to protect the right of individuals to have arms, the Supreme Court's earliest examinations of the topic also support an individualist reading of the Second Amendment. That individualist reading had only a limited effect because the Supreme Court in the nineteenth century was willing to give only a very limited acknowledgement of the full scope and effect of the Fourteenth Amendment. The first case alleging a violation of the Second Amendment was brought, ironically enough, by the

23. The Reconstruction Amendments’ Debates 209 (Alfred Avins, ed., 1967).

24. Jonathan Bingham, who authored the Section I of the Amendment, which included the Privileges or Immunities Clause, and introduced it before the House of Representatives and Jacob Howard, who introduced the Amendment in the Senate and explained the meaning of the Privileges or Immunities Clause before the upper chamber. Cong. Globe, 39th Cong., 1st Sess. 1088, 2765 (1866); Cong. Globe, 42d Cong., 1st Sess. app. 84 (1871).

25. See supra note 3 and accompanying text. 
federal government. In United States v. Cruikshank, federal authorities brought charges against William Cruikshank and his associates for violating the civil rights of a number of black men in Louisiana. ${ }^{26}$ The charges were brought under the Enforcement Act of 1870, which had been passed in order to allow federal prosecutions for violations of the civil rights of the newly freed Negro population and also to protect the rights of white unionists in the South. Among the charges brought against Cruikshank and his associates were that he and his mob of followers had violated the rights of a group of black men to peaceably assemble and to keep and bear arms. The black men were going to the polls and they were armed, anticipating possible attack from a hostile white mob.

The Supreme Court, in its examination of the Federal Government's charges, overturned the convictions of Cruikshank and the others on the grounds that Congress did not have the power to criminalize deprivations of constitutional rights committed by private citizens. The First and Second Amendments, according to the opinion authored by Chief Justice Morrison R. Waite, protected Americans from acts of Congress-infringements by the Federal Government.

Cruikshank was part of a broader process by which the Supreme Court in the 1870s and 1880s was about the business of blunting the constitutional revolution that the Fourteenth Amendment was meant to be. That amendment was clearly meant to revise antebellum notions of race and status, notions that were encapsulated in Dred Scott v. Sandford, in which Chief Justice Roger B. Taney reasoned that blacks, slave or free, could not be citizens because citizenship "would give to persons of the negro race... the right... to keep and carry arms wherever they went," along with other "individual rights." 27 The Fourteenth Amendment was also intended to redesign American federalism by requiring the states to respect basic rights of their citizens. This was a repudiation of the view the Supreme Court had put forward in Barron v. Baltimore, an 1833 case in which the Court held that the Fifth Amendment, and by implication other sections of the Bill of Rights were not limitations on state governments. ${ }^{28}$ Finally, the Fourteenth Amendment, like its counterparts the Thirteenth and Fifteenth Amendments, was designed to make Congress a major player in the enforcement of the new constitutional order. This reflected the view of many in the Reconstruction-era congresses that the Court had made fatally flawed decisions in Barron and Dred Scott..$^{29}$

A series of Supreme Court decisions helped to quash much of this Constitutional Revolution in the nineteenth century. Cruikshank ${ }^{30}$ in 1875 and later the

26. Johnson ET AL., supra note 22, at 299.

27. See Dred Scott v. Sandford, 60 U.S. (19 How.) 393, 417, 450 (1857), superseded by constitutional amendment, U.S. Const. amend. XIV.

28. Barron v. Baltimore, 32 U.S. (7 Pet.) 243 (1833).

29. See Clayton E. Cramer, Nicholas J. Johnson \& George A. Mocsary, "This Right Is Not Allowed by Governments that Are Afraid of the People": The Public Meaning of the Second Amendment when the Fourteenth Amendment Was Ratified, 17 Geo. Mason L. Rev. 823 (2010).

30. United States v. Cruikshank, 92 U.S. 542 (1875). 
Civil Rights Cases $^{31}$ in 1883 put strict limits on Congress's ability to enact protective legislation under the authority of the Fourteenth Amendment. The Slaughterhouse Cases of 1873 stripped the new Amendment's Privileges or Immunities Clause, the provision that was meant to apply the Bill of Rights to the states, of any effective meaning. ${ }^{32}$ The Second Amendment would also fall victim to this judicial counter-revolution. In the 1886 case of Presser v. Illinois, the Supreme Court held that the Second Amendment only restrained the federal government, not the states. ${ }^{33}$ Curiously enough, Justice William Woods, Presser's author, also stated that the states, putting the Second Amendment aside, could not disarm their populations because doing such would deprive the government of its reserve militia-the population at large. ${ }^{34}$

Presser would have profound consequences for the development of a jurisprudence concerning the right to arms in federal courts. Most gun control measures historically have been enacted by the states rather than the federal government. The doctrine that the Second Amendment only limited the Federal Government therefore meant that federal courts were not asked the hard questions concerning which kinds of regulations were consistent with a constitutional right to bear arms. ${ }^{35}$ Judicial scrutiny of the Second Amendment would be limited to examinations of a relatively limited set of federal laws, not the broader universe of state and local firearms regulations. The Supreme Court's next major encounter with the Second Amendment was in hearing a challenge to the National Firearms Act of 1934 (NFA), the federal government's first national gun-control measure.

\section{ii. From Miller to Heller}

Before District of Columbia v. Heller confirmed in 2008 that the Second Amendment guaranteed and codified a preexisting individual right to keep and bear arms, ${ }^{36}$ the U.S. Supreme Court had last directly addressed the Second Amendment in the 1939 case of United States v. Miller. ${ }^{37}$ Jack Miller was caught in possession of a sawed-off shotgun in violation of the NFA. ${ }^{38}$ Rejecting the district court's holding that the Act violated the Second Amendment, the Court held,

31. The Civil Rights Cases, 109 U.S. 3 (1883) (holding that Congress lacked authority under the Fourteenth Amendment to outlaw private racial discrimination).

32. The Slaughterhouse Cases, 83 U.S. 36 (1873).

33. Presser v. Illinois, 116 U.S. 252 (1886).

34. Id. at 265 .

35. State courts had, however, examined the question in detail, especially in the nineteenth century. With very rare exceptions, they held that individuals possessed a right to arms. They differed, however, in the scope of the right. See Johnson ET AL., supra note 22, at 251-74, 321-39 (excerpting and citing cases and providing commentary).

36. District of Columbia v. Heller, 554 U.S. 570, 592 (2008).

37. United States v. Miller, 307 U.S. 174 (1939); George A. Mocsary, Explaining Away the Obvious: The Infeasibility of Characterizing the Second Amendment as a Nonindividual Right, 76 FordHAM L. REv. 2113, 2113-14 \& n.4 (2008).

38. Miller, 307 U.S. at 175. 
In the absence of any evidence tending to show that possession or use of a "shotgun having a barrel of less than eighteen inches in length" at this time has some reasonable relationship to the preservation or efficiency of a wellregulated militia, we cannot say that the Second Amendment guarantees the right to keep and bear such an instrument. Certainly it is not within judicial notice that this weapon is any part of the ordinary military equipment or that its use could contribute to the common defense. ${ }^{39}$

\section{Reviewing historical sources, the Court said,}

[T] he Militia comprised of all males physically capable of acting in concert for the common defense. "A body of citizens enrolled for military discipline." And further, that ordinarily when called for service these men were expected to appear bearing arms supplied by themselves and of the kind in common use at the time. ${ }^{40}$

The Court remanded for further proceedings. ${ }^{41}$ Although Miller is a confusing opinion which the Heller Court criticized as "virtually unreasoned," 42 a few basic points are readily ascertainable: First, if one assumes that "common defense" is a militia-only undertaking, Miller is fairly read as requiring some connection between the militia and the weapon in question. Second, if the Court believed that the arms-bearing right belonged to states rather than to individuals, ${ }^{43}$ it would not have remanded the case to determine whether the militiaconnection requirement of its holding was satisfied. ${ }^{44}$ Third, the Court did not hold that the NFA's regulation of short-barreled shotguns was per se constitutional.

39. Id. at 178 .

40. Id. at 179 .

41. Id. at 183 .

42. Heller, 554 U.S. at 624 n.24; see also Transcript of Oral Argument at 62, District of Columbia v. Heller, 554 U.S. 570 (2008) (No. 07-290) (Justice Anthony Kennedy referring to Miller as "deficient").

43. It is worth noting on this point that the Court adopted the second of the government's following two arguments in the case:

First, it argued that the Amendment "gave sanction only to the arming of the people as a body to defend their rights against tyrannical and unprincipled rulers" and "did not permit the keeping of arms for purposes of private defense." Thus, the right was "only one which exists where the arms are borne in the militia or some other military organization provided for by law and intended for the protection of the state." Second, the government argued that "the term 'arms' ... refers only to those weapons which are ordinarily used for military or public defense purposes and does not relate to those weapons which are commonly used by criminals."

Mocsary, supra note 37, at 2136-37 (quoting Brief of the United States at 12, 15, 18, United States v. Miller, 307 U.S. 174 (1939) (No. 38-696)) (internal citations omitted).

44. See Nelson Lund, Heller and Second Amendment Precedent, 13 Lewis \& Clark L. Rev. 335 , 338-39 (2009). 
Three years after Miller, the U.S. Court of Appeals for the First Circuit addressed a Second Amendment challenge to the Federal Firearms $\mathrm{Act}^{45}$ (FFA) in Cases v. United States. ${ }^{46}$ The court acknowledged that, under Miller, "the federal government... cannot prohibit the possession or use of any weapon which has any reasonable relationship to the preservation or efficiency of a well-regulated militia." 47 Yet in its next breath, it refused to apply an "outdated" Miller ostensibly for fear of allowing militia weapons into potentially criminal hands, stating that "some sort of military use seems to have been found for almost any modern lethal weapon." 48

The same year, the U.S. Court of Appeals for the Third Circuit likewise rejected a Second Amendment challenge to the FFA in United States v. Tot ${ }^{49}$ The court stated that the Second Amendment "was not adopted with individual rights in mind, but as a protection for the States in the maintenance of their militia organizations against possible encroachments by the federal power."50 Yet this position was at odds with both Miller $^{51}$ and Supreme Court precedent holding that the federal government had plenary power over the militia. ${ }^{52}$ The court concluded with the policy statement that " $[\mathrm{t}]$ he social end sought to be achieved by this legislation, the protection of society against violent men armed with dangerous weapons, all would concede to be fundamental in organized government." 53 Although the FFA was "stringent," the court held, it was not "so oppressive and arbitrary" that it "infringe[d] upon the preservation of the well-regulated militia protected by the Second Amendment." 54

A mere three years after Miller, then, federal appellate courts were already fomenting a fear that any serious enforcement of the Second Amendment might

45. The FFA regulated what one might today think of as "ordinary" firearms rather than what some consider more unusual weapons like machine guns and short-barreled shotguns that are still regulated by the NFA. Compare National Firearms Act of June 26, 1934, ch. 757, 48 Stat. 1236 (amended 1954), with Federal Firearms Act of June 30, 1938, ch. 850, 52 Stat. 1250 (repealed 1965).

46. Cases v. United States, 131 F.2d 916 (1st Cir. 1942).

47. Id. at 922 .

48. Id. The court applied what was essentially an intent-based test to conclude that Cases's firearm possession was not protected because he was neither affiliated with a military organization nor was his possession of his firearm at the time of his arrest in a nightclub connected with private preparation for military service. $I d$.

49. United States v. Tot, 131 F.2d 261 (3d Cir. 1942), rev'd, 319 U.S. 463 (1943).

50. Id. at 266 .

51. See supra text accompanying notes 37-38, 41-43.

52. See Selective Draft Law Cases, 245 U.S. 366, 374-83 (1918) (holding that Congress has the authority to abolish a state militia by bodily incorporating it into the federal army); Martin v. Mott, 25 U.S. (12 Wheat.) 19, 28-33 (1827) (holding that the President has the power to call the militia from state control into federal service); Houston v. Moore, 18 U.S. (5 Wheat.) 1, 24 (1820) (holding that federal militia legislation preempts state legislation); see also Perpich v. Dep't of Defense, 496 U.S. 334, 352-54 (1990) (holding that state militias may be called into federal service over state objection).

53. Tot, 131 F.2d at 271. The court ultimately rested its opinion on the principle that it was reasonable to forbid dangerous individuals, like the defendant, who had previously been convicted of a violent crime, from possessing firearms, and that such a regulation did not "infringe upon the preservation of the well regulated militia protected by the Second Amendment." Id. at 266-67.

54. Id. at $267,271$. 
lead to an increase in crime. In the coming decades, courts would continue to avoid Miller's militia-connection standard. Some avoided even addressing an asserted militia nexus by maintaining that the right belonged to states. ${ }^{55}$ Others fell further into the trap that the framers feared-that of giving government a monopoly on the tools of violence, and the federal government in particular a monopoly on military power ${ }^{56}$ - by resigning themselves to the view that state militias had effectively become federal entities that lost any connection to the Second Amendment when the Dick Act created the National Guard. ${ }^{57}$ Until Heller's forerunners began a reversal, ${ }^{58}$ former Harvard Law School Dean Roscoe Pound's 1957 vision of a judicial forcing of even a militia-centric version of the Second Amendment into desuetude had become the status quo. ${ }^{59}$

\section{iii. Heller and Beyond}

District of Columbia v. Heller addressed a claim that the District of Columbia's ban on keeping a handgun in the home for self-defense was unconstitutional. ${ }^{60}$ In holding that it was, ${ }^{61}$ the Court's analysis strongly implied that the Second Amendment also protected arms bearing outside the home. Significantly, a complete analysis of Heller's reasoning must account for the Court's

- noting that "the need for self-defense is most acute" in the home, implying that it is acute elsewhere, ${ }^{62}$

- listing a number of "longstanding" "presumptively lawful" arms-bearing regulations, including "longstanding prohibitions on the possession of firearms by felons and the mentally ill, or laws forbidding the carrying of firearms in sensitive places such as schools and government buildings, or laws imposing conditions and qualifications on the commercial sale of arms," without sanctioning a general ban on public carrying, suggesting that some regulation of arms-carriage outside the home was not presumptively lawful; ${ }^{63}$

55. United States v. Warin, 530 F.2d 103, 105-06, (6th Cir. 1976); see United States v. Oakes, 564 F.2d 384, 387 (10th Cir. 1977).

56. See Mocsary, supra note 37, at 2117, 2149, 2155-56, 2169.

57. United States v. Hale, 978 F.2d 1016, 1019 (8th Cir. 1992); United States v. McCutcheon, 446 F.2d 133, 135-36 (7th Cir. 1971); see supra note 51 and accompanying text.

58. The retreat began with United States v. Emerson, 270 F.3d 203 (5th Cir. 2001), which declared that the Second Amendment guaranteed an individual right to arms even absent a militia connection, and continued with Parker v. District of Columbia, 478 F.3d 370, 379 (D.C. Cir. 2007), cert. granted sub nom. District of Columbia v. Heller, 554 U.S. 570 (2007).

59. Roscoe Pound, The Development of Constitutional Guarantees of Liberty 90-91 (1957).

60. Heller, 554 U.S. at 573.

61. Id. at 635 . The Court also invalidated a D.C. law requiring that any firearm kept in the home be rendered inoperable. $I d$.

62. Id. at 628 (emphasis added).

63. Id. at 626-27 \& n.26 (emphasis added); see Michael P. O'Shea, Modeling the Second Amendment Right to Carry Arms (I): Judicial Tradition and the Scope of "Bearing Arms" for Self-Defense, 61 Aм. L. Rev. 585, 617 (2012). 
- holding that the Second Amendment protects an "individual right to possess and carry weapons in case of confrontation," in a world where most confrontations are not limited to the home and it is all but impossible for one not to leave home; ${ }^{64}$

- disaggregating the right to keep arms from the right to bear-or carryarms, which carrying is unlikely to refer to the home, especially given that keeping naturally refers to one's home; ${ }^{65}$

- relying on nineteenth century state case law that held that the right to bear arms mandated the legality of either concealed or open public carriage. ${ }^{66}$

A thorough reading of Heller, therefore, strongly suggests that the Supreme Court believed that the right to arms extended outside the home.

After McDonald v. Chicago declared that the Second Amendment protected a fundamental individual right against state encroachment, ${ }^{67}$ litigation over the scope of the right began in the lower courts. Notwithstanding Heller's implications, courts have, at best, mildly confined government regulation of public carry to a "may issue" permitting regime. ${ }^{68}$ At worst, they have outright defied decades of fundamental-right jurisprudence. Of the three cases to reach federal Courts of Appeal and hold that the challenged ban on public carry was unconstitutional, Moore v. Madigan, Peruta v. County of San Diego, and Palmer v. District of Columbia, only Moore resulted in the implementation of a "shall issue" permitting system. ${ }^{69}$ Despite reluctantly acknowledging Heller's implications in an intellectually honest manner and striking down Illinois' ban on public carriage, Moore explicitly sanctioned a may-issue regime. ${ }^{70}$ It was through the political process that shall-issue concealed carry was ultimately enacted in Illinois: A coalition ${ }^{71}$ of state legislators from Southern Illinois insisted on both a shall-issue licensing system and statewide preemption of local law to the contrary. They threatened not to pass any remedial legislation meeting Moore's requirements, which would have resulted in open carry throughout the state once Moore's self-imposed 180-day stay of its mandate expired.

64. Heller, 554 U.S. at 592 (emphasis added); see O'Shea, supra note 63, at 610-11.

65. Heller, 554 U.S. at 584.

66. Id. at 626; O'Shea, supra note 63, at 616.

67. McDonald v. City of Chicago, 561 U.S. 742,767 (2010).

68. "May issue" licensing systems grant state or local government officials discretion to grant permits to carry concealed weapons only to those who demonstrate a "need" more heightened than a general need for self-defense. "Shall issue" systems require government officials to grant licenses to all applicants who, typically, must pass a background check and successfully complete a firearm-safety class.

69. Palmer v. District of Columbia, 59 F. Supp. 3d 173, 183 (D.D.C. 2014), appeal dismissed, Palmer v. District of Columbia, No. 14-7180, 2015 WL 1607711 (D.C. Cir. Apr. 2, 2015) (mem.); Peruta v. County of San Diego, 742 F.3d 1144 (9th Cir. 2014), reh'g en banc granted, 781 F.3d 1106 (9th Cir. 2015); Moore v. Madigan, 702 F.3d 933 (7th Cir. 2012).

70. Moore, 702 F.3d at 941.

71. The coalition was bipartisan, with Democratic legislators supplying the critical votes. 
Peruta and Palmer did not fare so well. Peruta also recognized Heller's implications in striking California's may-issue system, as applied by the San Diego County Sheriff to require a specific, imminent threat against the individual. $^{72}$ The Ninth Circuit granted en banc rehearing. The en banc court upheld California's law, holding that even if either concealed or open carry had to be permitted, plaintiffs challenged only the concealed-carry permitting system, which, standing alone, was constitutional, and that the court did not have to consider California's ban on open carry. ${ }^{73}$ Yet, as the dissent points out, California completely banned open carry, even licensed open carry, after plaintiffs' initial challenge had been ruled on by the district court. ${ }^{74}$ Whereas plaintiffs had a plausible mode to exercise their constitutional right to public firearm carriage when they filed, that opportunity was foreclosed during the pendency of their and the government's appeals. ${ }^{75}$ The en banc majority was unconcerned with these developments.

Palmer struck the District of Columbia's ban on public carry. In its wake, the District enacted a may-issue statute that required a permit applicant to demonstrate, "at a minimum, ... a special need for self-protection distinguishable from the general community as supported by evidence of specific threats or previous attacks that demonstrate a special danger to the applicant's life ...."76 A lawsuit challenged the new regime, and the same district judge who decided Palmer enjoined the new law. ${ }^{77}$ The District appealed, and the U.S. Court of Appeals for the District of Columbia Circuit lifted the injunction. ${ }^{78}$ The D.C. Circuit vacated the District Court's injunction, and on remand, the District Court found the injunctive relief was not warranted. ${ }^{79}$ Another appeal has been filed. $^{80}$

Other challenges lost outright. ${ }^{81}$ Drake v. Filko, the most defiant of these cases, merits further discussion. At issue was New Jersey's may-issue statute requiring applicants for carry permits to show a "justifiable need to carry a handgun," by showing an "urgent necessity for self-protection, as evidenced by specific threats or previous attacks which demonstrate a special danger to the

72. Peruta, 742 F.3d at $1152-56$.

73. Peruta v. Cty. of San Diego, 824 F.3d 919, 927-28, 941-42 (9th Cir. 2016).

74. Id. at 950-52 (Callahan, J., dissenting).

75. Id. at $950-51$.

76. D.C. Code $\S 22-4506$ (a) (2014).

77. Wrenn v. District of Columbia, 107 F. Supp. 3d 1 (D.D.C.), vacated, 808 F.3d 81 (D.C. Cir. 2015).

78. Wrenn v. District of Columbia, 808 F.3d 81 (D.C. Cir. 2015).

79. Wrenn v. District of Columbia, No. CV 15-162 (CKK), 2016 WL 912174 (D.D.C. Mar. 7, 2016).

80. Notice of Appeal, Wrenn v. District of Columbia, No. 16-7025 (D.C. Cir. Mar. 15, 2016).

81. Drake v. Filko, 724 F.3d 426 (3d Cir. 2013) (upholding New Jersey's "justifiable need" requirement); Woolard v. Gallagher, 712 F.3d 865 (4th Cir. 2013) (upholding Maryland's "good and substantial reason" requirement); Peterson v. Martinez, 707 F.3d 1197 (10th Cir. 2013) (holding that public carry "does not fall within the scope of the Second Amendment's protections"); Kachalsky v. Cty. of Westchester, 701 F.3d 81 (2d Cir. 2012) (upholding New York's "proper cause" requirement), cert. denied sub nom. Kachalsky v. Cacace 133 S.Ct. 1806 (2013). 
applicant's life that cannot be avoided by means other than by issuance of a permit to carry a handgun." 82 The U.S. Court of Appeals for the Third Circuit first held that public carriage fell outside the scope of the Second Amendment's protection because the justifiable-need requirement was longstanding. ${ }^{83}$ Yet even if Heller's presumption of legality is based on the longstanding nature of a regulation-a questionable assertion because Heller did not say that longstandingness drove the presumption ${ }^{84}$ - the Drake majority made no serious effort to address plaintiffs' arguments rebutting the presumption. It first, without addressing Heller's analysis, dismissed plaintiffs' argument that either open or concealed shall-issue carry had to be permitted ${ }^{85}$ It then concluded that the two states' restrictive laws were longstanding on the ground that New Jersey's and New York's similar statutes had been in effect since 1924 and 1911, and that the felon-in-possession bans sanctioned by Heller were enacted in the same era. ${ }^{86}$ But as the Drake dissent points out, New Jersey allowed open carry until 1966, and "felon-in-possession laws have historical pedigrees that originated with the founding generation." 87 The majority made no effort to explain away these complications.

The Drake majority then performed what it termed "intermediate scrutiny" analysis, ${ }^{88}$ but which closely resembled rational basis review. Under the Third Circuit's version of intermediate scrutiny, the state bears the burden of showing that a given regulation does "not burden more [conduct] than is reasonably necessary" ${ }^{89}$ in attempting to achieve its stated end. Most significantly, the court relied entirely on the "predictive judgment of New Jersey's legislators" that limiting issuance of carry permits would enhance public safety. ${ }^{90}$ This predictive judgment was based on "no evidence at all." absolve the state from its burden by stating that, at the time that the statute in question was passed, Heller had not yet declared the Second Amendment to be an individual right, and that the legislators therefore could not have been expected to know that they should marshal evidence to support their predictive judgment. ${ }^{92}$ But a governmental entity may present, and a court may consider, evidence outside the legislative record when evaluating a law's constitutionality, as was the case in another Second Amendment decision on which the Drake

82. Drake, 724 F.3d at 428.

83. Id. at 431-34.

84. District of Columbia v. Heller, 554 U.S. 570, 626-27 \& n.26 (2007).

85. Drake, 724 F.3d at 433; see id., 724 F.3d at 449 (Hardiman, J., dissenting); supra text accompanying note 68 .

86. Id. at 433-34; see supra text accompanying note 63 .

87. Drake, 724 F.3d at 448-50 (Hardiman, J., dissenting).

88. Id. at 435 .

89. United States v. Marzzarella, 614 F.3d 85, 98 (3d Cir. 2010); Drake, 724 F.3d at 436 (citing Marzzarella, 614 F.3d at 98). Other Circuits require a "substantial fit." Drake, 724 F.3d at 436 n.14.

90. Drake, 724 F.3d at 437.

91. Id. at 454 (Hardiman, J., dissenting); see id. at 437-38 (citing no evidence supporting the predictive judgment).

92. Id. at 437-38. 
majority relied heavily. ${ }^{93}$ The court failed to explain why it was acceptable for New Jersey not to present evidence to support the continued justifiability of its prohibition.

The Third Circuit's actions are equivalent to a court upholding, after the ratification of the Fifteenth Amendment, ${ }^{94}$ a ban on freed slaves' voting that was passed before that amendment's ratification on the ground that the legislature that enacted the ban did not know at the time that such bans would eventually be constitutionally prohibited. Such undercutting of Supreme Court precedent and complacence in the face of legislative over-regulation of a fundamental right suggests that something other than a desire to control crime is at issue, as discussed next.

\section{UnDERENFORCEMENT OF THE SECOND AMENDMENT: ReCONSIDERING THE CONSEQUENCES}

Underenforcement of the Second Amendment as a constitutional norm has produced serious distortions in the criminal-law system by enabling the overcriminalization of the malum prohibitum offense of firearm possession. This Part describes the tactics used to make the distortions possible and the distortions' effects on ordinary peaceable citizens.

The vast majority of existing and proposed gun laws consist of some type of possessory offence. This has the potential to turn otherwise law-abiding, but unknowing or overburdened, firearm owners in to status criminals. Yet these offenses are an additional layer on top of those which already regulate the ways in which guns may be misused-murder, rape, armed robbery, and the like are (and should be) heavily sanctioned, and they often carry greater penalties when committed with a firearm. ${ }^{95}$ It is difficult to imagine that one undeterred by the sanctions for these crimes would be deterred by the potential penalty imposed by a possessory offence with a much lower chance of detection.

Indeed, firearms, unlike many other items subject to bans, have traditional lawful and legitimate uses, like enabling self-defense, preventing crime, and

93. Marzzarella, 614 F.3d at 100 (relying on a post-enactment study to determine whether a statute was a reasonable fit with the legislature's intent to prevent gun violence); see Nixon v. Shrink Mo. Gov't PAC, 528 U.S. 377, 393-95 (2000) (considering third-party evidence where "Missouri does not preserve legislative history"); Randall v. Sorrell, 548 U.S. 230, 253-56 (2006) (considering postenactment research and expert testimony developed specifically for litigation); United States v. Carter, 750 F.3d 462, 467-68 (4th Cir. 2014) (relying on post-enactment evidence to assess the merits of a Second Amendment claim); Moore v. Madigan, 702 F.3d 933, 937-41 (7th Cir. 2012) (same); United States v. Reese, 627 F.3d 792, 802-04 (10th Cir. 2010) (same); United States v. Yancey, 621 F.3d 681, 686 (7th Cir. 2010) (same). The Drake majority cited Marzzarella twenty-three times.

94. The Fifteenth Amendment provides in relevant part that " $[\mathrm{t}] \mathrm{he}$ right of citizens of the United States to vote shall not be denied or abridged by the United States or by any State on account of race, color, or previous condition of servitude." U.S. CONST. amend. XV $\S 1$.

95. Compare, e.g., 720 Ill. Comp. Stat. 5/11-1.20 (criminal sexual assault), with 720 Ill. Comp. Stat. 5/11-1.30 (aggravated criminal sexual assault). 
keeping harmful wild-animal populations in check. ${ }^{96}$ They also have positive values associated with them, like civic duty, self-sufficiency, self-discipline, and sportsmanship. ${ }^{97}$ This has been recognized by both the U.S. Supreme Court, and by the District of Columbia Court of Appeals in striking down a D.C. ordinance making it a felony to be present in a motor vehicle knowing that it contained a firearm:

[G]iven the "long tradition of widespread lawful gun ownership by private individuals in this country," the recent definitive recognition of a Second Amendment right to possess guns for self-protection, individuals (especially visitors from other jurisdictions) who do not happen to be well-versed in the intricacies of the District's firearms laws may not see anything wrong in the presence of a gun or realize that the local law may proscribe its possession or transportation. 98

96. The last item in this list may be counterintuitive to some. Yet to farmers, ranchers, states, and others whose economic well-being and safety are affected, controlling wild animals is exceedingly important. See, e.g., Ga. Dep't. of Natural Res., An Assessment of the Deer Population on Jekyll Island, Georgia AND the MANAGEMENT ImPLications 12-13 (2011), http://www.savejekyllisland.org/dnr_ deer_management_plan.pdf (stating that deer overpopulation was resulting in deer attacks on humans, vehicle collisions, landscaping damage, and other problems, and promoting sharpshooting and hunting as the preferred and cost-effective ways to control the number of deer); William F. Allan \& Joann K. Wells, Characteristics of Vehicle-Animal Crashes in Which Vehicle Occupants Are Killed, 6 TRAFFIC INJURY PREVENTION 56, 56-59 (2005) (reporting that vehicle-deer collisions cause about 200 deaths and $\$ 1.1$ billion in property damage per year); State Wildlife Bounty Laws by State, Born FreE USA, http://www.bornfreeusa.org/b4a2_bounty.php (last visited Mar. 5, 2014) (listing state bounties on harmful animals). And then there are wild pigs, which are notoriously destructive and have led some states to adopt liberal hunting policies where they are concerned. See, e.g., Damage by Pigs, Miss. ST. UNIV. (June 27, 2013), http://wildpiginfo.msstate.edu/damage-caused-by-pigs.html (estimating annual agricultural and environmental damage at $\$ 1.5$ billion); Rules for Shooting Feral Swine, Мich. Dep't Natural Res., http://www.michigan.gov/dnr/0,4570,7-153-10370_12145_55230230093-,00.html (last visited Feb. 17, 2014) (explaining that Michigan allows the year-round shooting of wild pigs).

97. See, e.g., President Theodore Roosevelt, Sixth Annual Message to Congress (Dec. 6, 1906) ("We should establish shooting galleries in all the large public and military schools, should maintain national target ranges in different parts of the country, and should in every way encourage the formation of rifle clubs throughout all parts of the land. The little Republic of Switzerland offers us an excellent example in all matters connected with building up an efficient citizen soldiery."); President Theodore Roosevelt, Seventh Annual Message to Congress (Dec. 3, 1907) ("While teams representing the United States won the rifle and revolver championships of the world against all comers in England this year, it is unfortunately true that the great body of our citizens shoot less and less as time goes on. To meet this we should encourage rifle practice among schoolboys, and indeed among all classes, as well as in the military services, by every means in our power. Thus, and not otherwise, may we be able to assist in preserving the peace of the world. Fit to hold our own against the strong nations of the earth, our voice for peace will carry to the ends of the earth. Unprepared, and therefore unfit, we must sit dumb and helpless to defend ourselves, protect others, or preserve peace. The first step-in the direction of preparation to avert war if possible, and to be fit for war if it should come- is to teach our men to shoot.").

98. Conley v. United States, 79 A.3d 270, 285 (D.C. 2013) (quoting Staples v. United States, 511 U.S. 600, 610 (1994) (internal citations omitted)). 
The Supreme Court has also held that the AR-15 rifle, the nation's most commonly owned style of rifle, ${ }^{99}$ was not of such "quasi-suspect character" that it would be acceptable to dispense with a mens rea requirement in a statute making it illegal to own one that fired more than one round per trigger pull. ${ }^{100}$

Nevertheless, many legislators and gun-control organizations endeavor to demonize both firearm owners and certain types of firearms. It is easier to convince the public that disfavored individuals and objects should be targeted by regulation. The next section discusses an example of how mass demonization of some semi-automatic rifles and their owners has been implemented in the public sphere. The section following the next discusses overcriminalization.

\title{
A. "Assault Weapons"-The Quintessential Demonization Campaign
}

Possession of most semi-automatic ${ }^{101}$ rifles is not regulated by the federal government or the states. Some states require permits for semi-automatic pistol possession, and most require it for carrying. Some semi-automatic firearms, however, have been designated "assault weapons" 102 by a number of states and localities, and have been regulated or banned. The first point to note is that assault weapons are not machine guns; they function identically to other semi-automatic rifles. Yet they have been demonized, along with their owners, via decidedly underhanded tactics.

In the mid-1980s Josh Sugarmann of the Violence Policy Center found that neither Americans nor the media were interested in banning handguns. A staunch gun-control proponent, he searched for a "a new topic in what has become to the press and public an 'old' debate." ${ }^{103} \mathrm{He}$ came up with the term "assault weapon" and reasoned that

\begin{abstract}
Assault weapons-just like armor-piercing bullets, machine guns, and plastic firearms-are a new topic. The weapons' menacing looks, coupled with the public's confusion over fully automatic machine guns versus semi-automatic assault weapons-anything that looks like a machine gun is assumed to be a machine gun - can only increase the chance of public support for restrictions on these weapons. ${ }^{104}$
\end{abstract}

99. NRA-ILA, Not Quite All "The Facts" About the AR-15. https://www.nraila.org/articles/20131108/ not-quite-all-the-facts-about-the-ar-15 ('[T]he AR-15 is 'America's most popular rifle' . . based upon recent firearm manufacturer reports showing that between 300,000 and 500,000 AR-15s are made annually for sale to the public .... Americans own about five million AR-15s") (quoting Brian Jones, Another AR-15 Rampage? Here Are The Facts About America's Most Popular Rifle, Bus. Insider (Nov. 1, 2013 3:08 PM), http://www.businessinsider.com/assault-rifle-weapon-ar-15-2013-11).

100. Staples, 511 U.S. at 618-19. Mr. Staples' AR-15 sometimes fired more than one round per trigger pull because of a defect.

101. A semi-automatic firearm fires one cartridge with each pull-and-release of the trigger.

102. "Assault rifle" is a related term.

103. Josh Sugarman, Violence Policy Ctr., Assault Weapons and Accessories in America (1988), http:// www.vpc.org/studies/awacont.htm (click on "Conclusion" hyperlink).

104. Id. (emphasis added). 
His strategy of relying on public's confusion to further his agenda worked. ${ }^{105}$ Seven states, the District of Columbia, and a few localities ${ }^{106}$ regulate or ban so-called assault weapons and the federal government regulated them from 1994 to $2004 .^{107}$ Firearms are characterized as assault weapons based almost entirely on having external attachments-like a vertical grip; a metal covering over the barrel to reduce burns; or a muzzle attachment that reduces the recoil, the flash of light associated with firing a rifle, or both-that do not change how the gun operates. ${ }^{108}$ The few covered features that a criminal shooter might use during a crime, like the ability to accept a bayonet, are non sequiturs - criminal bayonetings are unheard of. ${ }^{109}$

After Connecticut made its assault-weapon ban stricter in the wake of the atrocity at Newtown, Connecticut, one of this Article's authors was interviewed by local media for his opinion on the new law. ${ }^{110}$ Referring to the law's Sugarmannesque "physical characteristics test," he opined that the law should be unconstitutional because the test banned weapons based on arbitrary features. ${ }^{111}$ The Governor's office replied that "There's something unique about these weapons. [1] They're lightweight, [2] designed for military purposes, and [3] can fire a lot of bullets very quickly." "112 Anyone with a basic understanding of firearms, as one would expect the Governor's Undersecretary for Criminal

105. See Bruce H. Kobayashi \& Joseph E. Olson, In Re 101 California Street: A Legal and Economic Analysis of Strict Liability for the Manufacture and Sale of “Assault Weapons”, 8 STAN. L. \& Pol'y Rev. 41, 43 (1997). This is not the first time that a class of weapons has been demonized. In the 1960 s it was bolt-action military surplus rifles. In the 1970s it was handguns. In the 1980s it was "Saturday night specials."

106. The states are California, Connecticut, Hawaii, Maryland, Massachusetts, New Jersey, and New York. The localities include Chicago, Illinois; Cook County, Illinois; Highland Park, Illinois; Gary, Indiana; East Chicago, Indiana; New York City; and Boston.

107. 18 U.S.C. $\$ 922(v)$, amended by Public Safety and Recreational Firearms Use Protection Act, 1994, Pub. L. 103-322, § 110102(c), 108 Stat. 1796, 1996, repealed by Pub. L. 103-322 § 110105(2), 108 Stat. 1796, 2000.

108. Conn. Gen. Stat. § 53-202a (2013). Although some of these attachments are useful to persons using firearms for lawful self-defense, there is no evidence that such attachments increase a criminal's ability to commit a crime. A flash suppressor, for example, and as the name implies, suppresses the muzzle flash that occurs when a gun is fired. A barrel shroud prevents a firearm's operator from being burned by a firearm's potentially hot barrel. Neither assists materially, if at all, in the typical criminal shooting where the shooter may not fire many rounds, may not expect to survive the encounter, and is typically out in the open during the day rather than shooting from the cover of darkness. One might argue that these features are functional because some users will prefer them to others. But this is true of any physical feature on any firearm. A user will use the gun with which he or she is most comfortable because of stature, arm length, and the like, and can afford. The point is that the bullet fired from the weapon is no more dangerous than the bullet fired from a weapon without the proscribed features.

109. Internet searches on google.com and duckduckgo.com for "criminal bayoneting" and "bayoneting" yielded no crimes committed by bayonet.

110. Hugh McQuaid, Challenges Mulled as Gun Bill Becomes Law, CTNewsJunkie (Apr. 4, 2013), http://www.ctnewsjunkie.com/archives/entry/challenges_mulled_as_gun_bill_becomes_law/.

111. Id. He also correctly noted that a northeastern court would not likely strike the law. Shew v. Malloy, 994 F. Supp. 2d 234, 239 (D. Conn. 2014); Hugh McQuaid, Second Challenge To CT's New Gun Law Filed, CTNewsJunkie (May 22, 2013), http://www.ctnewsjunkie.com/archives/entry/ second_challenge_to_cts_new_gun_laws_filed/.

112. McQuaid, supra note 110. 
Justice Policy ${ }^{113}$ to have, will recognize the falsity in this statement: (1) Physics dictates that adding a piece of metal to the rifle-like a barrel shroud, vertical pistol grip, or bayonet mount-will make it heavier; (2) the firearms in question are in fact not the machine guns used by the military, but rather semi-automatic weapons with selected demonized features; ${ }^{114}$ and (3) the banned weapons can fire as rapidly as they could without the banned features. The Governor's office has, therefore, indirectly admitted that its law, at best, will not affect the results of unlawful shootings. ${ }^{115}$

Some are willing to go further, demonizing assault weapon owners. The rhetoric ranges from asserting that "there is no legitimate use for these weapons"116 to suggesting that "the only people who use them are mass murderers." ${ }^{117}$ This is by definition false. The AR-15 style of rifle, which is on practically every assault-weapon lists, has been owned by several million perfectly law-abiding Americans since it became available to the public in 1963. ${ }^{118}$

Demonizing firearms and their owners makes it possible to target them with criminalization tactics that decent people would not ordinarily consider acceptable, as the next section discusses.

\section{B. Overcriminalization}

Gun-control laws have a tendency of turning into criminals peaceable citizens whom the state has no reason to have on its radar. This suggests that the motive for these laws is more a kind of cultural imperialism than a real hope that the measures they seek to impose will reduce crime. They are malum prohibitum offenses ${ }^{119}$ that ostensibly seek to prevent already-prohibited secondary con-

113. Id.

114. See supra text accompanying notes 101-07.

115. The law may in fact cause criminals to use lighter weapons, working against the Governor's office's stated goals of restricting lightweight weapons.

116. Press Release, Office of Sen. Chuck Schumer, Warner, Dewine, And Chafee Join Feinstein \& Schumer In Effort To Renew Assault Weapons Ban (Feb. 24, 2004), https://www.legistorm.com/stormfeed/ view_rss/391373/member/85.html.

117. Debate Between Rep. Wiliam McColluym and Sen. Charles Schumer, Lifting the Ban?, PBS (Mar. 21, 1996), available at http://www.freerepublic.com/focus/news/1033940/posts; see, e.g., 159 Cong. Rec. S2717 (daily ed. Apr. 17, 2013) (statement of Sen. Menendez) ("There is simply no rationale for having these weapons on our streets - unless your intent is to inflict terror and destruction and mass casualties."); Brady Center to Prevent Gun Violence, Assault Weapons: "Mass Produced MAYHEM" (2008), available at http://www.bradycampaign.org/sites/default/files/mass-produced-mayhem. pdf ("[W]hy should civilians be allowed to wield these weapons of war?"); see generally id.

It should be noted that so-called assault weapons are used in a small fraction of criminal shootings. Christopher S. Koper Et Al., Jerry Lee Center of Criminology, An Updated Assessment of the Federal Assault Weapons Ban: Impacts on Gun Markets and Gun Violence, 1994-2003, at 2 (2004), available at https://www.ncjrs.gov/pdffiles1/nij/grants/204431.pdf ("AWs were used in only a small fraction of gun crimes prior to the [1994] ban: about $2 \%$ according to most studies and no more than $8 \%$.").

118. See supra note 99 and accompanying text.

119. See supra note 13 and accompanying text. 
duct, ${ }^{120}$ and which sometimes impose penalties greater than those for heinous malum in se offenses. ${ }^{121}$ The statutes are often easy for the unknowing to violate, and they impose exceedingly harsh penalties.

Federal law makes it illegal for felons, those under indictment for felony charges, domestic-violence misdemeanants, users of controlled substances, adjudicated "mental defectives," illegal aliens, dishonorable dischargees, renouncers of US citizenship, and some under restraining orders against intimate partners to possess firearms. ${ }^{122}$ These are, for the most part, uncontroversial. It is nevertheless unnerving that citizens, on average, apparently commit three felonies per day, ${ }^{123}$ and that the mean felon-in-possession sentence is in almost all years greater than five years imprisonment. ${ }^{124}$ Some at the Bureau of Alcohol, Tobacco, Firearms and Explosives consider it the agency's "'bread-and-butter' violation." 125

The Migratory Bird Treaty Act provides what is almost a caricature of how easy it is to become a federal felon. The act outlaws, inter alia, the possession, sale, and barter of any bird, or feather thereof, covered by the Act. ${ }^{126}$ The penalty for feather possession is a strict-liability misdemeanor, while the penalty for knowingly bartering a feather is a felony punishable by up to two years' imprisonment and $\$ 2,000 .{ }^{127}$ The Act's mens rea requirement refers only to "the putative offender's actions rather than to the legality of those actions," leaving "no room for ignorance of the law." 128 In other words, a husband and wife who, walking down the street on a lazy Sunday morning pick up two interesting feathers, shed by a bird in flight that no longer needs them, become subject to misdemeanor indictment. If they find that each likes the other's feather more than the one that he or she picked up, and they exchange feathers, they become subject to felony indictment, a lifetime firearm ban, and several years in prison if they possess a gun.

120. See supra text accompanying note 95.

121. See supra note 14 and accompanying text.

122. 18 U.S.C. $\$ 922(\mathrm{~g})(2010)$.

123. See Harvey Silverglate, Three Felonies A Day: How the Feds Target the Innocent (2011).

124. 18 U.S.C. § 924; Kevin A. McDonald, Felon in Possession Sentencing Under The Federal Guidelines, Considering State Sentences, 36 Seton Hall Legis. J. 106, 129 (2011).

125. McDonald, supra note 124, at 108 (quoting JAY Dobyns \& Nils Johnson-Shelton, No Angel: My Harrowing Undercover Journey To The Inner Circle Of The Hells Angels 10 (2010)).

126. 16 U.S.C. $\$ 703$.

127. 16 U.S.C. $\$ 707$.

128. United States v. Pitrone, 115 F.3d 1, 7 (1st Cir. 1997); accord United States v. Engler, 806 F.2d 425, 431-36 (3d. Cir. 1986); United States v. Gayhart, 827 F. Supp. 2d 736, 738 \& n.1 (E.D. Ky. 2011). The Courts of Appeals are not in complete agreement about the constitutionality of Act's lack of a scienter requirement. See, e.g., United States v. CITGO Petroleum Corp., 801 F.3d 477, 488-89 (5th Cir. 2015) (agreeing with the Eighth and Ninth Circuits that that the Act addresses only intentional behavior and rejecting the views of the Second and Tenth Circuits to the contrary). Although this split among the courts focuses primarily on the Act's restrictions on "kill[ing]" or "tak[ing]" a migratory bird, rather than its prohibitions on "sell[ing]" or "barter[ing]," it does suggest that courts are concerned about the overcriminalization of activities covered by the Act. 16 U.S.C. $§ \S 703,707$. 
Although federal law does not generally mandate firearm registration, ${ }^{129}$ some states and localities do. Registration is usually required only for handguns and so-called assault weapons, but some jurisdictions, like New York City, require registration of all firearms. ${ }^{130}$ Others, like Massachusetts, mandate registration of firearm owners. ${ }^{131}$ Anyone who does not register becomes a status criminal upon coming into possession of a firearm, with potentially appalling consequences. Massachusetts, whose Fox-Bartley Law imposes a mandatory one-year sentence for unlicensed carriage of a firearm, provides a stark example.

In 1986, Sylvester Lindsey was sentenced to a mandatory one-year prison term for carrying a handgun that he used to defend himself from a knifewielding attacker after that attacker, a convicted felon, had previously threatened him and attacked him with a knife. ${ }^{132}$ The jury found him guilty of unlawful carrying of a firearm. ${ }^{133}$ The Supreme Judicial Court, first held that the defense of necessity was not available to Lindsey because the previous attacks and threats were not immediate enough to warrant them. ${ }^{134}$ But it then noted that "[t]he threat of physical harm was not a general one," that Lindsey may have saved his life by using his gun to defend himself, and that he was an upstanding citizen, but that the courts had no choice but to imprison him for a year. ${ }^{135}$ Three years later, a Massachusetts trial court, unhindered by a mandatorysentence requirement, imposed a suspended sentence on a 44 year-old man for twice raping an eight-year-old girl. ${ }^{136}$ Similar sentencing for rapists (including child rapists) and violent attackers continues in Massachusetts. ${ }^{137}$ A legal regime that is willing to imprison a disfavored Lindsey while allowing child rapists to be free strongly suggests that, at least for some,

129. Most notably, fully automatic weapons, short-barreled rifles and shotguns, silencers, and weapons like grenades "deemed destructive" devices must be registered with the Department of the Treasury. 26 U.S.C. $§ 5841$. Some states prohibit possession of such weapons. E.g., 720 ILl. Comp. Stat. 5/24-1(a)(7).

130. E.g., N.Y.C. Admin. CodE $§ 10-131$ (mandating registration of all firearms).

131. Mass. Gen. Laws ch. 140, $\$ 129$ B (requiring would-be owners to obtain a firearm identification card)

132. Commonwealth v. Lindsey, 489 N.E.2d 666, 669 (Mass. 1986).

133. Id. at 666 .

134. Id. at 667. It "became a real and direct danger once again," according to the court, when defendant was attacked the second time. $I d$. at 669 .

135. Id. at 669.

136. See Richard Kindleberger, Ruling in Beverly Assault Case Leaves Scars, Bos. Globe, Mar. 26, 1989 , at 25 .

137. E.g., Alyssa Dandrea, Massachusetts Man Sentenced in Franklin Pierce University Sexual Assault, SentinelSource.com (Apr. 29, 2015), http://www.sentinelsource.com/news/local/massachusettsman-sentenced-in-franklin-pierce-university-sexual-assault/article_039f98b9-4fe5-5c4b-a66a-2618 d061a4f8.html (suspended sentence for misdemeanor sexual assault and second-degree felony assault); Rape Victim Sues Massachusetts for Forcing Her into Relationship with Attacker, RT.com (Aug. 22, 2013), https://www.rt.com/usa/rape-victim-sues-massachusetts-855/ (suspended sentence for child rapist); Regional Digest, Worcester Telegram \& Gazette, Sept. 5, 2008, at B2 (probation and monitoring for two counts of indecent sexual assault and battery; probation and monitoring for indecent assault and battery on a person 14 or older, rape of a child with force, and statutory rape of a child). 
Gun control is a moral crusade against a benighted barbaric citizenry. This is demonstrated ... by the ineffectualness of gun control in preventing crime, and by the fact that it focuses on restricting the behavior of the law-abiding rather than apprehending and punishing the guilty.... Gun owners are routinely portrayed as uneducated, paranoid rednecks fascinated by and prone to violence....

When columnist Carl Rowan preaches gun control and uses a gun to defend his home, when Maryland Gov. William Donald Schaefer seeks legislation year after year to ban semiautomatic "assault weapons" whose only purpose, we are told, is to kill people, while he is at the same time escorted by state police armed with large-capacity $9 \mathrm{~mm}$ semiautomatic pistols, it is not simple hypocrisy. It is the workings of that habit of mind possessed by all superior beings who have taken upon themselves the terrible burden of civilizing the masses .... ${ }^{138}$

For Mr. Lindsey, the relatively new adage of preferring to be judged by twelve than carried by six became all too real.

New York's SAFE Act is close to a worst-case scenario for gun owners. It is best known for its assault-weapon ban, but it also makes it illegal both to own magazines capable of holding more than ten rounds of ammunition, and to load such magazines with more than seven rounds. ${ }^{139}$ There is an exception, however, to the seven-round limit for shooting-sports participants ${ }^{140}$ that illustrates the elitist underpinnings of much of modern gun control: the law makes it a felony to load eight or more rounds into a magazine to defend oneself at home, ${ }^{141}$ while completely accommodating the playing of a game. ${ }^{142}$ An official from the Governor's office remarked of the Act's recently enacted registration requirement that "[m]any of these assault-rifle owners aren't going to register; we realize that," and he acknowledged "widespread violations" of the law. ${ }^{143}$ In the process of acknowledging that its law won't work, in other words, the Governor's office also acknowledged that it was prepared to turn the otherwise-

138. Jeffrey R. Snyder, A Nation of Cowards, 113 Pub. INT. 40, 46-47 (1993).

139. N.Y. Penal LaW $§ 265.00(23), 265.37$ (McKinney 2013).

140. Id. $\S 265.20 .7-\mathrm{f}$.

141. Id. $\$ 265.37$.

142. Cf. Michael P. O'Shea, The Steepness of the Slippery Slope: Second Amendment Litigation in the Lower Federal Courts and What It Has to Do with Background Recordkeeping Legislation, 46 Conn. L. Rev. 1381, 1401 (2014). In rare fashion, the U.S. Court of Appeals for the Second Circuit declared this provision of the Act unconstitutional because "New York has failed to present evidence that the mere existence of this load limit will convince any would-be malefactors to load magazines capable of holding ten rounds with only the permissible seven.” N.Y. State Rifle and Pistol Ass'n v. Cuomo, 804 F.3d 242, 264 (2d Cir. 2015).

143. Fredric U. Dicker, Hit Us with Your Best Shot, Andy!, N.Y. Post (Jan. 21, 2013), http:// nypost.com/2013/01/21/hit-us-with-your-best-shot-andy/; see also George A. Mocsary, Insuring Against Guns?, 46 Conn L. Rev. 1209, 1259 (2014) "Many firearm owners fear registration because they believe that it is a prerequisite to firearm confiscation ... . Such a concern is understandable given the admissions to this effect by proponents of . . gun control, and that ' $\mathrm{t}$ ] $\mathrm{g}$ he progression from registration to confiscation has occurred both domestically and internationally.," 
law-abiding owners of an estimated one million of these demonized weapons ${ }^{144}$ into status criminals.

A few additional examples characterize the overcriminalization problem. In 2006 Corporal Melroy Cort, a veteran of the United States Marine Corps, was arrested for having an unregistered pistol in the District of Columbia. Cort had lost both his legs as a result of injuries suffered from an improvised explosive device $^{145}$ during his third tour of duty in Iraq. He was confined to a wheelchair. He was going to Walter Reed Army Hospital in the District of Columbia, and had a permit to carry his pistol in his home state of Ohio. According to Cort, his commanding officer had advised him that he could bring the pistol from Ohio to D.C. as long as he put the pistol in Walter Reed's armory upon reaching the facility. The firearm was discovered after Cort and his wife had gotten a flat tire and he pulled into a repair shop. Reluctant to leave the gun alone with the repair shop crew, Cort put the weapon in his jacket pocket. Someone saw this and called the police. Cort was arrested. ${ }^{146}$

Cort was charged with three counts of carrying a pistol without a license, possession of an unregistered firearm, and possession of ammunition. The D.C. Attorney General's Office, which handles prosecutions for local offenses in Washington, had the discretion not to prosecute, or to prosecute only on misdemeanor charges. It decided to charge the disabled veteran with a felony. The consequences of a felony conviction would have meant not only time in prison but also the loss of his veteran's benefits. Cort was assigned a public defender who advised him to plead guilty. Fortunately, the gravely wounded Marine decided to represent himself. In his own words: "I wasn't going to plead guilty and lose everything." At trial the judge ordered him to stick strictly to the facts of his arrest and his possession of the pistol. Cort nonetheless managed to get enough of the surrounding information-his good record, his permit, his wounds in the service of his country - to the jury. It probably helped that Cort was in a wheelchair. If the police, the prosecutors and the judge couldn't see rank injustice when it stared them in the face, twelve ordinary citizens could. The jury acquitted Cort on all charges except for the misdemeanor of illegally possessing ammunition. The prosecutor's attempt to, in effect, destroy a decent man who had been confused about the law's requirements and who had lost far too much in the service of the nation had failed. Cpl. Cort returned to his wife and three-month-old daughter in Ohio. ${ }^{147}$

Ronald Dixon was also a veteran. Unlike Cort, but similar to most veterans, his service did not result in life altering injuries. Mr. Dixon, a Jamaican immigrant, had served in the Navy and later went on to a civilian career as a computer engineer. In 2003, he moved from Florida to New York City, bringing

144. Id. The Act prohibits disclosure of the number of weapons registered.

145. Improvised explosive devices are commonly referred to as IEDs.

146. Keith Alexander, Marine Amputee Acquitted on Gun Possession Charge, Wash. Post (Jan. 14, 2009), http://www.washingtonpost.com/wp-dyn/content/article/2009/01/13/AR2009011302840.html.

147. Id. 
with him a pistol he had owned in the southern state. New York City has highly restrictive licensing requirements with what are, for many, prohibitive fees to own a gun in one's dwelling. These fees are combined with a review and approval period that frequently takes six months or more to run its course. The whole process is designed to make it prohibitive for ordinary citizens to own firearms for self-defense, even in the home. Despite Heller and McDonald, the U.S. Court of Appeals for the Second Circuit sanctioned this regime of restrictive firearms regulation as constitutional. ${ }^{148}$

On Saturday December 14, 2002, Dixon shot and wounded Ivan Thompson-a burglar who had, according to press accounts, a fourteen-page rap sheet including burglary and larceny. Thompson broke into Dixon's house at 7:30 A.M. while Dixon's twenty-three-month-old son and eight-year-old daughter were sleeping. The shooting was justified. Indeed, then Brooklyn District Attorney Charles Hynes declared "Clearly he [Dixon] was justified in shooting this burglar, and the burglar is going to get as much jail time as we can get him." Despite this, the New York prosecutor was determined to prosecute Dixon for illegal possession of a pistol. Initially the Brooklyn District Attorney wanted to have Dixon accept a plea bargain and serve four weekends in New York's notorious and dangerous Rikers Island prison, a deal that Dixon turned down. The case gained notoriety on the conservative talk show circuit including on Fox News's then popular "Hannity and Colmes" show, which featured a debate format between a conservative and liberal news commentator. Dixon was finally allowed to plead guilty to disorderly conduct and serve a three-day sentence. The agreement ensured that Dixon would not have a criminal record. If New York's strict laws concerning simple possession of a pistol in the home were designed to prevent violent criminals from getting their hands on dangerous weapons, in Mr. Dixon's case they ensnared a man who even authorities recognized was exercising the most basic of human rights, defending his home and family. The media hue and cry, the publicizing of an obviously absurd application of the law, probably played a key role in preventing an egregious miscarriage of justice. ${ }^{149}$

Our final example involves the New Jersey case of Shaneen Allen. Ms. Allen is a black mother of two young children who worked as a phlebotomist. ${ }^{150} \mathrm{~A}$ resident of Philadelphia, Ms. Allen had a Pennsylvania permit to carry a pistol. In October of 2013 she was driving in Atlantic County New Jersey when she was stopped by a police officer for an unsafe lane change. She informed the officer that she had a pistol in the car and that she had a Pennsylvania permit.

148. Kwong v. Bloomberg, 773 F.3d 160, 168 (2d Cir. 2013).

149. Patrice O'Shaughnessy, Gun-Ho for Brooklyn Dad: Intruder Shooter's New Hero to Many, N.Y. DAILY News (Feb. 2, 2003), http://www.nydailynews.com/archives/news/gun-ho-brooklyn-dad-intrudershooter-new-hero-article-1.666088; Neil S. Friedman, No Criminal Record for Canarsie Dad Who Shot Burglar, CANARSIE Courier (Jun. 26, 2003), http://www.canarsiecourier.com/news/2003-06-19/TopStories/ 010.html.

150. A phlebotomist is a medical technician who specializes in drawing blood. 
She was arrested for violating New Jersey's strict gun control laws under which almost no ordinary citizens get licenses to carry firearms. ${ }^{151}$

Shaneen Allen's mistake was believing that her Pennsylvania permit, like her driver's license, would be valid in other states. It was not, and as we all learned, even before first year criminal law, "ignorance of the law is no excuse." But Allen's case should give one pause about applying that ancient maxim too rigorously. Perhaps in some dark, distant past, the maxim made perfect sense. Crimes consisted of actions that were universally (the efforts of our undergraduate anthropology instructors notwithstanding) regarded as evil. The law, using Latin, called such crimes malum in se, inherently evil. ${ }^{152}$ The law could quite reasonably say that a defendant did not have to consult the penal code to realize that murder, rape, or robbery were crimes. And the defendant's claim that he was ignorant of the prohibitions against such actions could reasonably and summarily be dismissed. But crimes which are simply malum prohibitum? ${ }^{153}$ One state requires that authorities issue permits to carry pistols to all individuals who do not have disqualifying felony records, another employs a very restrictive licensing regime essentially depriving all but an elite few of the privilege of carrying firearms for self-protection, while a third state allows firearm carriage without any permit. Confusion in this regard is not the kind of malicious intent that should qualify for a felony conviction.

Atlantic County prosecutor Jim McClain, however, was not receptive to Allen's mistake-of-law excuse. Nor was he inclined to go easy on the mother of two who had no prior criminal record. McClain had the option of recommending that Allen be placed in a diversionary program for first time offenders of victimless crimes. If placed in that program, she could have avoided jail time. Instead McClain was going forward with a prosecution that would have resulted in a three-year prison sentence for Ms. Allen. That sentence would have caused the devastating loss of her children and her job. ${ }^{154}$

Yet McClain was not always so unaccommodating toward defendants to diversionary programs. When Baltimore Ravens Running Back Ray Rice punched and knocked-out his wife in an Atlantic City Hotel, McClain was willing to let the NFL player enter a diversionary program and avoid prison. For the Philadelphia medical technician and mother who misunderstood what her permit allowed, the New Jersey prosecutor was inclined to be less charitable. ${ }^{155}$

151. Radley Balko, Shaneen Allen, Race and Gun Control, WAsH. Post (Jul. 22, 2014), https:// www.washingtonpost.com/news/the-watch/wp/2014/07/22/shaneen-allen-race-and-gun-control/.

152. See supra note 14 and accompanying text.

153. See supra note 13 and accompanying text.

154. Id.

155. Radley Balko, Prosecution of Shaneen Allen Moves Forward, WAsh. Post (Aug. 7, 2014), https://www.washingtonpost.com/news/the-watch/wp/2014/08/07/prosecution-of-shaneen-allen-movesforward/; Glenn Harlan Reynolds, Carrying a Gun Worse than Beating Your Wife, USA TodaY (Aug. 10, 2014), http://www.usatoday.com/story/opinion/2014/08/10/ray-rice-shaneen-allen-gun-column/ $13862831 /$. 
A statement by one New Jersey gun control advocate, Brian Miller, gives an indication that one reason for the harsh application of the state's gun control statute is pure deterrence divorced from balancing considerations of justice or proportionality, or even a strong connection between applied means and desired ends:

Fortunately, the notoriety of this case will make it less likely Pennsylvanians will carry concealed and loaded handguns in New Jersey, thereby making them and the Garden State safer from gun violence. ${ }^{156}$

The Shaneen Allen story would ultimately have a happy ending, but once again that happy ending had at least as much to do with the case's notoriety and political considerations as it did with safeguards built into the law. The case attracted nationwide media coverage. That coverage doubtless caused District Attorney Jim McClain to reconsider allowing Allen to participate in the diversion program. On April 2, 2015, Governor Chris Christie pardoned Shaneen Allen. To what extent the pardon was motivated by Governor's Christie's efforts at the time to get the Republican nomination for president, and to what extent it was prompted by the merits of the case, will probably never be fully known. In any event, the Philadelphia mother's ordeal was over. ${ }^{157}$

Some observers might argue that we should be able to count on a certain amount of reasonable behavior on the part of law enforcement charged with applying the law. Police and prosecutors presumably have discretion precisely because we want them to concentrate their efforts on dangerous criminals, not people who have committed otherwise harmless technical violations of the law or, worse, people who have made legal mistakes through inadvertent errors. As the preceding examples illustrate, the record in many firearms-restrictive jurisdictions indicates a willingness to zealously prosecute-and indeed attempt to destroy the lives of-essentially peaceable citizens caught up in technical violations of firearms laws. Whether these efforts are motivated by a genuinealthough in our view misguided-concern for public safety, or by the fact that police and prosecutors see peaceable citizens as easy targets that can allow law enforcement agencies and District Attorney's offices to pad both arrest and conviction records, we cannot say. In any event, the failure of the Courts to robustly enforce Second Amendment rights has left ordinary citizens, who live their lives with no intent to harm others and who have not taken any actions that have brought or threaten injury to their fellow citizens, vulnerable to the full weight of the criminal justice system.

156. Balko, supra note 151.

157. Prosecutor: Shaneen Allen Can Enter Diversion Program, Associated Press (Sept. 25, 2014), available at http://nj1015.com/prosecutor-shaneen-allen-can-enter-diversion-program/; Charles C. W. Cooke, Governor Christie Pardons Shaneen Allen, NaT'L Review (Apr. 2, 2015), http://www.nationalreview.com/corner/416383/governor-christie-pardons-shaneen-allen-charles-c-w-cooke. 


\section{CONCLUSION}

The criminalization tactics discussed herein are not a recent discovery. Queen Elizabeth I, in a 1600 proclamation, said that guns were being carried by "common and ordinary persons traveling the highway," whom she equated with "ruffians \& other lewd and dissolute men." 158 In 1415, crossbows were denounced as nefarious weapons of highwaymen, and Kings Henry VII and Henry VIII banned them for all but the wealthy; the Swiss, meanwhile, treated the crossbow as an iconic weapon of national independence. ${ }^{159}$

It is no justification to point to an absolute number of firearm injuries to support the notion that banning private gun ownership would make everyone safer. There is a great deal of disagreement among experts about the effect of private firearm ownership on unlawful shootings and crime deterrence. ${ }^{160}$ The frequency of firearm accidents is miniscule when compared to deaths and injuries from other sources or to the size of the American population. ${ }^{161}$

158. 3 Tudor Royal Proclamations 218 (Dec. 21, 1600).

159. JoHNSON ET AL., supra note 22, at 82.

160. Notable works finding that private firearm ownership has beneficial effects include JoHN R. LotT, JR. More Guns, Less Crime (3d ed. 2010) (finding that private firearm ownership leads to less crime); Gark Kleck \& Marc Gertz, Armed Resistance to Crime: The Prevalence and Nature of Self-Defense with a Gun, 86 J. CRIM. L. \& CRIMINology 150 (1995) (estimating 2,549,862 defensive gun uses (DGUs) per year). On the other side are Ian Ayres \& John J. Donohue III, Shooting Down the “More Guns, Less Crime” Hypothesis, 55 Stan. L. Rev. 1193 (2003); Philip J. Cook, Jens Ludwig \& David Hemenway, The Gun Debate's New Mythical Number: How Many Self-Defense Uses Per Year?, 16 J. Pol'y Analysis \& Mgmt. 463 (1997) (expressing skepticism about the accuracy of Kleck and Gertz's DGU estimate, but acknowledging that their methodology was sound). Other experts find that private firearm ownership has very little effect on crime. E.g., Carlisle E. Moody \& Thomas B. Marvell, The Debate on Shall-Issue Laws, 5 ECON J. WATCH 269 (2008) (finding that the only statisticallysignificant long-term effect of liberalizing concealed carry only is to reduce assaults). See also JoHNSON et al., supra note 22, at 911 (collecting sources).

161. In 2010, the U.S. population was about 309.3 million. U.S. CENSUS BurEaU, U.S. AND WorLd Population Clock, http://www.census.gov/popclock/ (last visited Oct. 16, 2015). The following table shows the number nonfatal and fatal of firearm accidents, incidents, and self-harm in 2010:

\begin{tabular}{|l|r|r|r|r|r|r|}
\hline & \multicolumn{2}{|c|}{ Nonfatal } & \multicolumn{2}{c|}{ Fatal } & \multicolumn{2}{c|}{ Total } \\
\hline Accidents & 14,161 & $20 \%$ & 606 & $2 \%$ & 14,767 & $14 \%$ \\
\hline Self-Harm & 4,683 & $6 \%$ & 19,392 & $62 \%$ & 24,035 & $23 \%$ \\
\hline Assaults & 53,738 & $74 \%$ & 11,078 & $36 \%$ & 64,816 & $63 \%$ \\
\hline Total & $\mathbf{7 2 , 5 4 2}$ & $\mathbf{1 0 0 \%}$ & $\mathbf{3 1 , 0 7 6}$ & $\mathbf{1 0 0 \%}$ & $\mathbf{1 0 3 , 6 1 8}$ & $\mathbf{1 0 0 \%}$ \\
\hline
\end{tabular}

Nonfatal Injury Reports, 2001-2011, Centers for Disease Control \& Prevention, http://webappa.cdc.gov/sasweb/ncipc/nfirates2001.html (last visited Apr. 15, 2014) (select either "Unintentional," "Assault-All," or "Self-Harm"; then select "Firearm"; and finally select "2010" and "All Ages"); Fatal Injury Reports, National and Regional, 1999-2010, Centers for Disease Control \& Prevention, http://webappa.cdc.gov/sasweb/ncipc/mortrate10_us.html (last visited Apr 15, 2014) (select either "Unintentional," "Homicide," or "Suicide"; then select "Firearm"; and finally select "2010" and "All Ages").

By way of comparison, falling accidents caused 9,146,026 injuries and 26,009 deaths. Nonfatal Injury Reports, 2001-2011, Centers For Disease Control \& Prevention, http://webappa.cdc.gov/sasweb/ ncipc/nfirates2001.html (last visited Apr. 15, 2014) (select either "Unintentional,"; then select "Fall"; 
Evidence also conflicts on whether firearm availability causes more suicide or merely shifts suicides from other sources to firearms. ${ }^{162}$

With such little clarity, there is no compelling justification for deploying the power of the state, via possessory offenses with draconian penalties, against individuals who want to defend themselves and their families, and who have done no other wrong. This is doubly true in a world where a felony conviction can destroy one's life, not to mention the lives of one's family members who may find themselves without a breadwinner or, worse, in foster care. The laws' collateral effect is to inhibit positive gun ownership without impacting the negative-proponents and opponents of gun control agree that criminals will not heed firearms restrictions. ${ }^{163}$

Firearms laws thus fall more harshly on peaceable citizens willing to defend themselves than on violent criminals. The state is able to enact these kinds of malum prohibitum offenses because their targets have been demonized to the point where it is possible to treat them as something less than full citizens.

and finally select "2010" and "All Ages"); Fatal Injury Reports, National and Regional, 1999-2010, Centers for Disease Control \& Prevention, http://webappa.cdc.gov/sasweb/ncipc/mortrate10_us.html (last visited Apr 15, 2014) (select "Unintentional"; then select "Fall"; and finally select "2010" and "All Ages").

162. Compare, e.g., Gary Kleck, Targeting Guns, Firearms and Their Control 275-79 (1997) with Harvard School of Public Health, Firearm Access Is a Risk Factor for Suicide, http://www.hsph.harvard.edu/means-matter/means-matter/risk (collecting research suggesting a link between firearms availability and suicide rates) (last visited Oct. 19, 2015). "[P]rivate firearms ownership is almost completely illegal in Japan, and is heavily restricted in Russia, but each of these countries has a per capita suicide rate more than double that of the United States." JohnSON et al., supra note 22 (citing WorLd HeALTH ORG., Suicide Rates (per 100,000) by Country, Year and Gender (2003), http://www.who.int/ mental_health/prevention/suicide/suiciderates/en/).

163. Cf. Mocsary, supra note 143, at 1229 n.125, 1262 (2014) (discussing expert agreement that criminals would not heed a mandate to register or insure their firearms). 